\title{
Increased CXCL8 Expression Is Negatively Correlated with the Overall Survival of Patients with ER-Negative Breast Cancer
}

\author{
QI FANG ${ }^{1}$, XUFEN WANG $^{1}$, GUANGHUA LUO $^{2}$, MIAOMEI YU ${ }^{2}$, XIAOYING ZHANG $^{2 *}$ and NING XU ${ }^{3 *}$ \\ Department of ${ }^{1}$ Breast Surgery and ${ }^{2}$ Comprehensive Laboratory, \\ the Third Affiliated Hospital of Soochow University, Changzhou, P.R. China; \\ ${ }^{3}$ Division of Clinical Chemistry and Pharmacology, \\ Department of Laboratory Medicine, Lund University, Lund, Sweden
}

\begin{abstract}
Background: $C$-X-C motif chemokine ligand 8 (CXCL8) is a multi-functional chemokine and has important roles during tumor formation and development. It was previously reported that increased CXCL8 protein levels occurred in certain patients. Materials and Methods: In the present study, we examined levels of CXCL8 mRNA in breast cancer tissues and analyzed its levels in correlation to patients' clinical data and 10-year overall survival (OS). Results: Our results clearly demonstrated that the level of CXCL8 mRNA was significantly higher in patients without estrogen receptor expression. The receiver operating characteristic curve indicated that the best cut-off value for CXCL8 expression was 3.095 for predicting patient's OS Conclusion: The present study demonstrated that higher CXCL8 mRNA levels in breast cancer tissues together with estrogen receptor negativity was associated with significantly shorter OS, and could be applied as a negative risk factor for 10-year $O S$.
\end{abstract}

Breast cancer, a most common malignant tumor in women with high biological heterogeneity, is characterized by the diversity of clinical prognosis. Prolonged exposure to excess estrogen has been regarded as one of the important factors for initiation and development of breast cancer (1). Estrogen

*These Authors contributed equally to this study.

Correspondence to: Dr. Xiao-ying Zhang, Comprehensive Laboratory, the Third Affiliated Hospital of Soochow University, Changzhou 213003, P.R. China. Tel: +86 13961159966, Fax: +86 51986621235, e-mail: zhangxy6689996@163.com and Ning Xu, MD, Ph.D., Division of Clinical Chemistry and Pharmacology, Department of Laboratory Medicine, Lund University, S-22185 Lund, Sweden. Tel: +46 736395642, Fax: +46 46130064, e-mail: ning.xu@med.lu.se.

Key Words: Breast cancer, $C X C L 8$, estrogen receptor, progesterone receptor, overall survival. receptor-alpha $(\mathrm{ER} \alpha)$ and -beta $(\mathrm{ER} \beta)$ are involved in mediating the major biological and pathological effects of estrogen $(2,3)$. ER $\alpha$ status has been generally used as an important parameter in breast cancer management because ER $\alpha$-positive breast cancers exhibit less aggressiveness and invasiveness than do ER $\alpha$-negative breast tumors, which have a worse prognosis. Currently, clinicopathological parameters are still conventionally applied as the practical guidance for clinical treatment and as predictors for patient prognosis $(4,5)$. However, the role of $\operatorname{ER} \beta$ in initiation and development of breast cancer and its clinical significance are still not clearly known (6). Based on the status of ER $\alpha$, progesterone receptor (PR) and human epithelial growth factor receptor-2 (HER2/Neu; ERBB2), breast cancer is divided in five subclasses. Among which, triple-negative breast cancer (TNBC), which is negative for expression of $\mathrm{ER} \alpha$ and PR, and with low expression of HER2/Neu, accounts for $20-25 \%$ of the breast cancer (7-9). Therefore, in order to identify new prognostic biomarkers useful for defining patients with a specific subclass of breast cancer being at high risk for shorter overall survival (OS) is of great significance for selecting appropriate approaches for therapeutic treatments.

$\mathrm{C}-\mathrm{X}-\mathrm{C}$ motif chemokine ligand 8 ( $C X C L 8$, also known as interleukin-8), an inflammatory chemokine (chemotaxis cytokine) containing the cysteine (C)-any amino acid (X)cysteine (C) (CXC) motif, acts through two receptors, namely CXCR1 (IL8RA) and CXCR2 (IL8RB) (10). CXCR2 is known to be involved in mediating the biological and pathological effects of $C X C L 8$ and other related CXC chemokines. It has been well documented that CXCL8 contributes to human cancer progression in autocrine and paracrine manners. Multiple mechanisms $(11,12)$ should be involved in $C X C L 8$ action, including both direct and indirect effects, e.g. angiogenesis, tumor cell growth and migration, attraction and infiltration of inflammatory cells. CXCL8 is known to possess tumorigenic and proangiogenic properties in vivo. Increased expression of $C X C L 8$ has been detected in 
many human tumor types, including breast cancer. Higher expression of $C X C L 8$ was reported to be associated with poor prognosis in certain patients with cancer $(13,14)$. However, it is still unclear whether abnormal overexpression of CXCL8 is related to the prognosis in Chinese patients with ER $\alpha$-negative breast cancer as it has been reported that TNBC in Chinese populations exhibits different patterns of relapse (15).

Based on the potential roles of $C X C L 8$ in ER $\alpha$-negative breast cancer, the present study aimed to investigate whether CXCL8 expression together with other clinically available prognostic variables is related to long-term prognosis in Chinese patients with ER $\alpha$-negative breast cancer and 10-year OS.

\section{Materials and Methods}

Patients and tissue samples. A total of 62 patients with primary breast cancer (all females aged between 30 and 84 years, median age of 50 years) who were hospitalized in the Third Affiliated Hospital of Soochow University from January 2003 to December 2003 were recruited in the present study. All the patients underwent modified radical operations and were followed-up to the end of September 2015. All the tumor samples were excised and quickly frozen in liquid nitrogen after resection and preserved at $-80^{\circ} \mathrm{C}$ until use for nucleotide analyses. All the tissue samples were histopathologically examined. They were all defined as invasive ductal breast cancer. In the present study, no patient was given any treatments before surgery. After surgery, all the patients received common anthracycline-based chemotherapy, but no patient was treated with humanized antibody to HER2 (trastuzumab) although trastuzumab was approved in 2002 in China. All the ER $\alpha$-positive patients had routinely received a standard endocrinotherapy. However, most patients stopped continuing endocrinotherapy by themselves after 2-3 years and only a few patients with ER $\alpha$-positive breast cancer continued endocrinotherapy for about 5 years. As several patients were unable to continue or complete the standardized endocrinotherapy, they were excluded from the data analyses.

The median follow-up time was 149.63 months (range=16.83161.87 months) and terminated at September 30. 2015. The patients lost to follow-up and suspended cases were censored. The characteristics of the patients are listed in the Table I. The protocols of the present study were approved by the Institutional Ethics Committee of the Third Affiliated Hospital of Soochow University [(2001)KENo.1(R01)] and all the patients gave their written informed consent to use of their specimens and data.

Extraction of total RNA, reverse transcription and polymerase chain reaction $(R T-P C R)$. Before RNA extraction, frozen sections of the specimens were examined histologically to ensure that they were representative of the tumor tissue. Total RNA of breast cancer tissue was extracted using total RNA isolation classic kit according to the instructions provided in the kit (SNBC, Shanghai, China) and treated with RNase-free DNase I (TaKaRa, Kyoto, Japan) for $30 \mathrm{~min}$ at $37^{\circ} \mathrm{C}$ to remove residual DNA. RNA quality and its integrity were verified using a 2100 Bioanalyzer (Agilent Technologies, Santa Clara, CA, USA).

A standard CXCL8-containing plasmid was diluted in a 10 -fold series within the range of $10^{8}-10^{1}$ with Tris-EDTA buffer. Each
Table I. Relationship between mRNA levels of $C$-X-C motif chemokine ligand 8 (CXCL8) and patient clinical parameters.

\begin{tabular}{|c|c|c|c|c|}
\hline \multirow[t]{2}{*}{ Clinical characteristic } & \multirow[t]{2}{*}{$\mathrm{N}$} & $C X C L 8 / G A P D H$ & \multirow{2}{*}{$\begin{array}{l}\text { Wilcoxon } \\
\text { - value* }\end{array}$} & \multirow{2}{*}{$p$-Value* } \\
\hline & & Median (IQR) & & \\
\hline \multicolumn{5}{|l|}{ Age, years } \\
\hline$\leq 50$ & 34 & $2.69(1.10-8.98)$ & 506 & 0.677 \\
\hline$>50$ & 28 & $2.48(1.08-9.24)$ & & \\
\hline \multicolumn{5}{|l|}{ Lymph node metastasis } \\
\hline No & 40 & $1.30(1.07-8.15)$ & 500 & 0.381 \\
\hline Yes & 22 & $2.69(1.55-9.92)$ & & \\
\hline \multicolumn{5}{|l|}{ Tumor size, $\mathrm{cm}$} \\
\hline$\leq 2$ & 36 & $3.16(1.18-11.60)$ & 555 & 0.217 \\
\hline$>2$ & 26 & $2.15(1.02-4.57)$ & & \\
\hline \multicolumn{5}{|l|}{ Estrogen receptor $\alpha$} \\
\hline- & 22 & $7.38(2.33-18.07)$ & 596 & 0.022 \\
\hline+ & 40 & $1.92(1.08-4.33)$ & & \\
\hline \multicolumn{5}{|l|}{ Progesterone receptor } \\
\hline- & 24 & $3.14(1.51-11.45)$ & 501 & 0.520 \\
\hline+ & 38 & $2.35(1.10-8.96)$ & & \\
\hline \multicolumn{5}{|l|}{ HER2 } \\
\hline- & 36 & $2.59(1.14-8.61)$ & 434.5 & 0.638 \\
\hline+ & 26 & $2.60(1.07-17.61)$ & & \\
\hline \multicolumn{5}{|l|}{ P53 } \\
\hline- & 40 & $2.90(1.14-11.60)$ & 540.5 & 0.141 \\
\hline+ & 22 & $2.34(1.02-3.67)$ & & \\
\hline \multicolumn{5}{|l|}{ Chemotherapy } \\
\hline Yes & 53 & $2.54(1.08-9.16)$ & 244 & 0.920 \\
\hline No & 9 & $2.65(1.13-9.58)$ & & \\
\hline
\end{tabular}

CXCL8: C-X-C Motif Chemokine Ligand 8; IQR: interquartile range. *Wilcoxon rank-sum test.

concentration of standard plasmid DNA sample was amplified by conventional PCR. The PCR-amplified product was separated in $1 \%$ agarose electrophoresis and stained with ethidium bromide. The size of polymerase chain reaction-amplified $C X C L 8$ fragment was $87 \mathrm{bp}$ (Figure 1). This indicated that the maximal resolution of the conventional PCR assay was $10^{3}$ copies per reaction. When the diluted CXCL8 standard solutions were quantitatively detected by real-time quantitative (q)PCR, the maximal resolution of this method was 10 copies per reaction and there was a linear relationship between the copy number of $C X C L 8$ standard and the $\mathrm{Ct}$ value.

Total RNA $(2 \mu \mathrm{g})$ was used to synthesize cDNA by reverse transcription. The first-strand cDNAs were synthesized by using Revert Aid first-stand cDNA synthesis kit (MBI Ferments Inc, Ontario, Canada) according to the instructions provided in the kit. The sequences for the primers for $C X C L 8$ and Glyceraldehyde-3phosphate dehydrogenase $(G A P D H)$ and Taqman probe were designed with primer design software as follows: CXCL8: forward primer: 5'-CTCTTGGCAGCCTTCCTGATT-3', reverse primer: 5'TATGCACTGA CATCTAAGTTCTTTAGCA-3'; CXCL8 probe: 5'FAM-CTTGGCAAAACTGCACC TTCACACAGA-TAMRA-3'; GAPDH: forward primer: 5'-GGAAGGTGAAGGTCGGAGTC-3', reverse primer: 5'-CGTTCTCAGCCTT GACGGT-3'; GAPDH probe: 5'-FAM-TTTGGTCGTATTGGGCGCCTG-TAMRA-3'). These primers and probes were synthesized by Shanghai Shenyou 


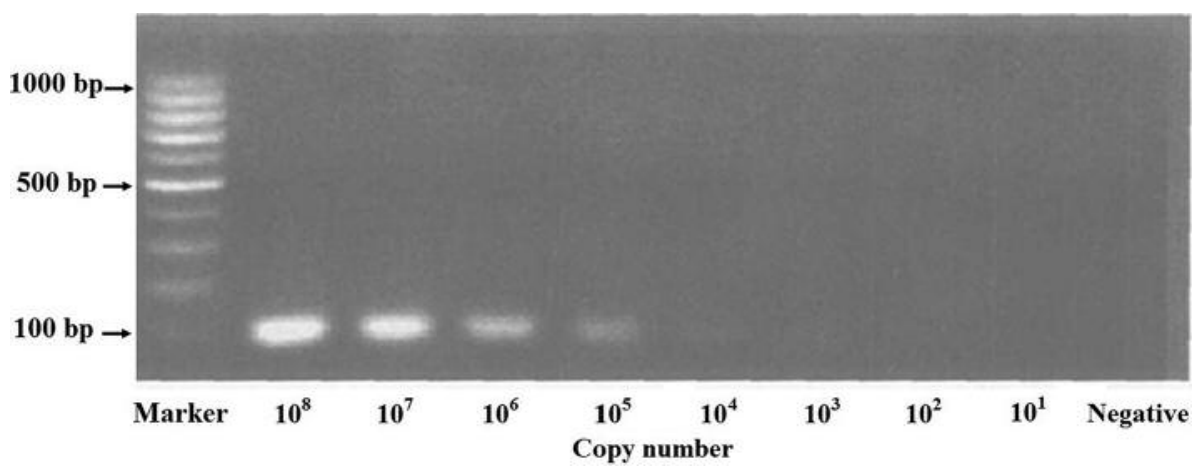

Figure 1. The agarose electrophoresis image of conventional polymerase chain reaction-amplified C-X-C motif chemokine ligand 8 (CXCL8) fragment.

Biotechnology, Ltd. (Shanghai, China). The PCR reaction for each target fragment was performed in total volume of $25 \mu$ l containing $2 \mu \mathrm{l}$ of cDNA template, $2.5 \mu \mathrm{l}$ of $10 \times$ buffer, $1.5 \mu \mathrm{l}$ of $\mathrm{MgCl}_{2}$ $(25 \mathrm{mM}), 0.5 \mu \mathrm{l}$ of $4 \times \mathrm{dNTPs}(10 \mathrm{mmol} / \mathrm{l}), 0.1 \mu \mathrm{l}$ of $100 \mu \mathrm{M}$ primers and probes and $0.5 \mu \mathrm{l}$ of DNA polymerase. The thermal cycling conditions included the following steps: $180 \mathrm{~s}$ at $50^{\circ} \mathrm{C}, 300 \mathrm{~s}$ at $95^{\circ} \mathrm{C}$, followed by 40 cycles of 2 -step PCR consisting of $20 \mathrm{~s}$ at $95^{\circ} \mathrm{C}, 60 \mathrm{~s}$ at $60^{\circ} \mathrm{C}$ (collecting fluorescence signal). All PCRs were performed on a LightCycler PCR system (Roche Company, Indianapolis, IN, USA). The mRNA levels of $C X C R 8$ and GAPDH were quantitated based on their standard curves.

CXCL8 standard curve was established by plotting the known copy numbers of the positive $C X C L 8$ template against the corresponding $\mathrm{Ct}$ values. For each sample, the PCR assay was repeated three times and the mean value was taken as the expression of CXCL8 in that sample. The RT-qPCR reaction system for GAPDH was the same as that for $C X C L 8$. The relative expression levels of $C X C L 8$ gene were calculated by normalizing $C X C L 8$ levels with the corresponding levels of GAPDH (CXCL8/GAPDH) and calculated based on CXCL8 standard curve to obtain the relative expression of $C X C L 8$ gene.

Immunohistochemistry. Formalin-fixed and paraffin-embedded tissues were cut into $3-\mu \mathrm{m}$-thick consecutive sections, dewaxed in xylene and rehydrated in graded ethanol solutions. Polyclonal rabbit antibody against human HER2 and P53 (DAKO Company, Fuzhou, Fujian, China) and corresponding polyclonal mouse antibodies against human ER $\alpha$ and PR (MXB Biotechnologies, Fuzhou, PR China) were used. There were two steps in EnVision IHC staining and color development, 3,3'-diaminobenzidine (DAB) was used as the color reagent, and phosphate-buffered saline was used as substitute for the primary antibodies and taken as the negative control. Tumors were considered positive when there were at least $1 \%$ positively stained tumor nuclei in the sample on testing in the presence of expected reactivity of internal (normal epithelial elements) and external controls $(16,17)$.

Immunostaining was scored by two pathologists. The intensity (I) of staining was graded on a scale of $0-3+$ with 0 representing no detectable staining and $3+$ representing the strongest staining. The four strongest staining regions were randomly selected under a 400x field. In each of the four regions, the rate of positive cell staining (R) under a $400 \times$ field was calculated and defined as follows: 0 . no staining; $1, \leq 10 \%$ tumor cells with staining; $2,11-50 \%$ tumor cells with staining; 3, 51-75\% tumor cells with staining; and 4, $>75 \%$ tumor cells with staining. Samples with scores $<3$ were considered negative, while those with scores $\geq 3$ were considered positive. Histochemistry score $=\mathrm{I} \times \mathrm{R}(18)$.

Tumors were considered as HER2-positive when cells exhibited strong membranous staining (3+). Tumors exhibiting 0 or $1+$ staining for HER2 protein expression were considered to be negative. In cases of equivocal membrane staining (score $2+$ ) for HER2, fluorescence in situ hybridization was used to evaluate HER2/neu gene amplification $(16,17)$.

Statistical analyses. Statistical analyses were performed with the $\mathrm{R}$ software, version 3.0.3 (http://journal.r-project.org/). Breast carcinoma-specific OS was defined as the time from the date of diagnosis to death if the patient died from breast carcinoma. Wilcoxon rank-sum test was used to examine the distribution of quantitative CXCL8 levels according to clinicopathological parameters. Survival curves were estimated by the Kaplan-Meier method, and the curves were compared with the log-rank test in univariate analyses. To examine the association of CXCL8 and clinicopathological parameters with OS, the Cox proportional hazards regression model was applied for calculating the hazard ratios (HR) and for corresponding 95\% confidence interval $(95 \%$ CI). Forward stepwise regression was used to calculate the multivariate HRs. A $p$-value of less than 0.05 was considered as statistically significant. The receiver operating characteristic (ROC) curve was defined as a plot of test sensitivity as the Y-axis versus its 1 -specificity as the $\mathrm{X}$-axis, which was conducted to determine the cut-off value of $C X C L 8$ expression level for predicting 10-year OS of breast cancer patients. Then, the area under the curve (AUC) of the ROC was used to assess the predictive validity.

\section{Results}

Clinical characteristics and distribution of relative expression of $C X C L 8$. The relative mRNA levels of $C X C L 8$ (i.e. the ratio of $C X C L 8 / G A P D H$ ) in breast cancer tissues of all 62 patients were examined. The patient's clinical parameters and the distribution of relative expression of CXCL8 are shown in Table I. There were no significant differences (Wilcoxon rank-sum test) in mRNA expression 


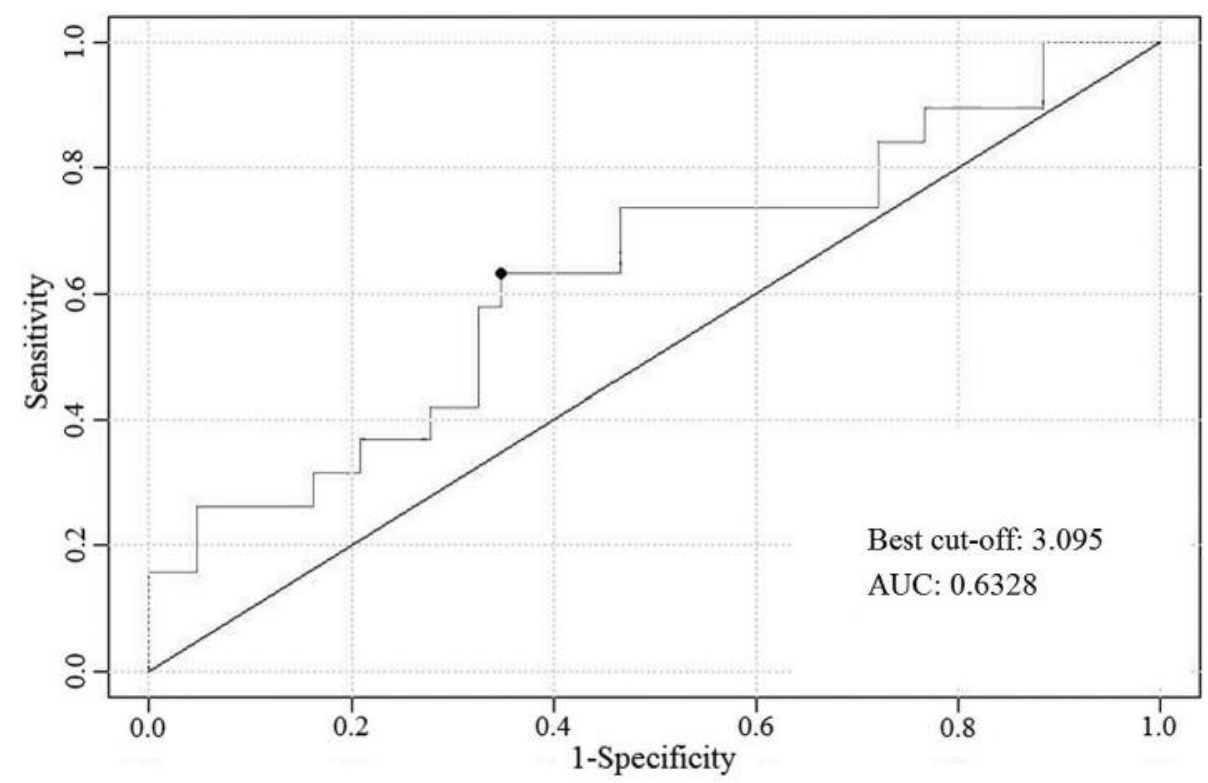

Figure 2. Receiver operating characteristic curve based on the relative mRNA level of C-X-C motif chemokine ligand 8 (CXCL8). AUC: Area under the ROC curve.

of $C X C L 8$ in terms of patient's age, lymph node metastatic status, tumor size, PR status, HER2, p53 and chemotherapy. The relative mRNA levels of $C X C L 8$ in ER $\alpha$-negative breast cancer tissues were significantly higher than those in ER $\alpha$ positive breast cancer tissues (Wilcoxon rank-sum test, $p=0.022$ ). Thereafter we performed an interaction test between paired variables on clinicopathological characteristics but their interaction showed no statistical significance (data not shown).

Association of CXCL8 level and clinical parameters in relation to patient prognosis. In the present study, the patients were followed-up for 10 years and the 10-year OS rates were analyzed. Based on the receiver operating characteristic (ROC) curve analysis (Figure 2), the optimal cut-off point of CXCL8 expression was found to be 3.095 for 10 -year OS rates. The sensitivity, specificity, area under the ROC curve (AUC) and the 95\% CIs were 63.16\%, 65.12\%, 0.6328 and $0.4758-0.7898$, respectively. At a median followup of 149.63 months (range $=16.83-161.87$ months), $70.97 \%$ $(44 / 62)$ of all patients were alive.

The univariate prognostic factors for OS are shown in Table II. Patients with ER $\alpha$-negative tumor $(\mathrm{HR}=3.11$, $p=0.015)$ and relative $C X C L 8$ expression value of 3.095 or more (HR=2.58, $p=0.047$ ) had a significantly lower rate of 10 -year OS than did patients with the ER $\alpha$-positive tumor with relative CXCL8 expression value of $<3.095$.

We further divided patients into four different subgroups according to their ER $\alpha$ status and the expression level of
CXCL8 (as shown in Table III). Compared other subgroups, the ER $\alpha$-negative group with higher expression of $C X C L 8$ had a significantly poorer 10 -year OS rate of $35.7 \%(p<0.001)$. After adjusting for age, tumor size, PR status, HER2, p53, chemotherapy and lymph node metastatic status, the multiadjusted HR for ER $\alpha$ negativity together with high expression of CXCL8 inversed to 16.19 (95\% CI=3.32-78.96).

The results of log-rank testing shown in Figure 3 demonstrate that the ER $\alpha$ status and $C X C L 8$ mRNA level significantly influenced 10-year OS $(p=0.001$ and $p=0.039$, respectively). When the CXCL8 level was used as a continuous variable, the HR was 1.01 (95\% CI=1.00-1.01; $p=0.027)$. Multiple stepwise linear regression analysis revealed that tumor size $>2 \mathrm{~cm}$ ), ER $\alpha$ negativity and high mRNA level of $C X C L 8$ were negative risk factors for 10year OS ( $p=0.009, p=0.028$ and $p=0.022$, respectively) (Table IV).

\section{Discussion}

It is well documented that elevated expression of $C X C L 8$ can contribute to cancer progression. A number of studies have highlighted the prognostic and predictive significance of CXCL8 in different types of cancers, including ovarian (19), colon $(20,21)$, pancreatic $(22)$, bladder $(23)$, and prostate cancer (24), leukemia (25) and melanoma (26). However, the association of $C X C L 8$ level and clinical parameters with long-term OS rates of patients with breast cancer has yet to be reported as far as we are aware. In the present study, we 

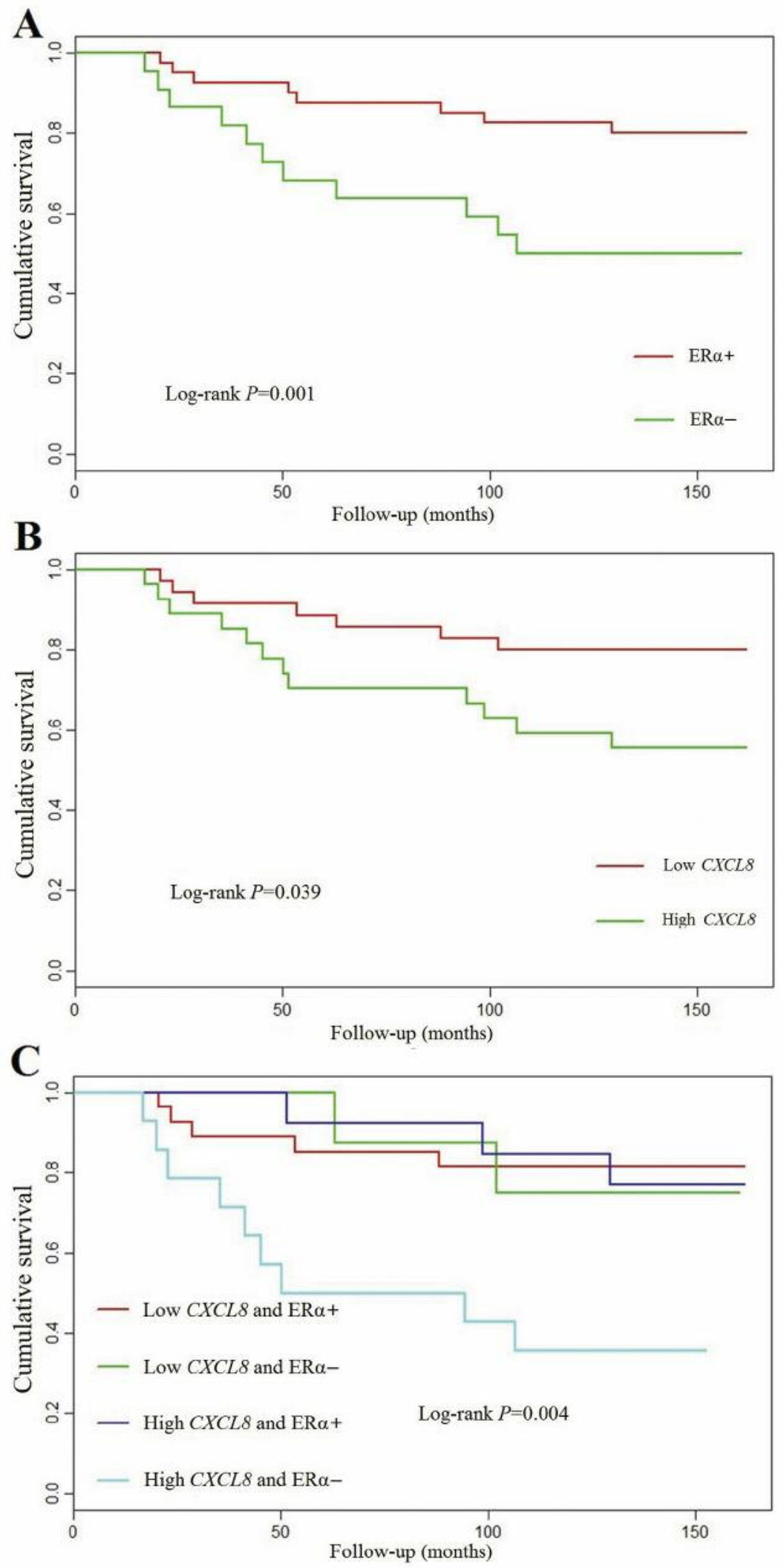

Figure 3. Comparison of survival curves according to estrogen receptor (ER) status (A), C-X-C motif chemokine ligand 8 (CXCL8) mRNA level (B), and ER status with CXCL8 mRNA level (C). 
Table II. Univariate analysis of patient overall survival.

\begin{tabular}{|c|c|c|c|c|}
\hline \multirow[t]{2}{*}{ Clinical parameter } & & \multirow[t]{2}{*}{ 10-Year OS } & \multicolumn{2}{|c|}{ Univariate } \\
\hline & & & HR $(95 \% \mathrm{CI})$ & $p$-Value \\
\hline Age, years & $>50$ vs. $\leq 50$ & $68 \%$ vs. $71 \%$ & $1.12(0.45-2.75)$ & 0.811 \\
\hline Lymph node metastasis & No vs. yes & $73 \%$ vs. $68 \%$ & $0.79(0.30-2.08)$ & 0.637 \\
\hline Tumor size, $\mathrm{cm}$ & $>2 v s . \leq 2$ & $58 \%$ vs. $78 \%$ & $2.32(0.93-5.78)$ & 0.070 \\
\hline Estrogen receptor $\alpha$ & $-v s .+$ & $50 \%$ vs. $80 \%$ & $3.11(1.25-7.74)$ & 0.015 \\
\hline Progesterone receptor & $+v s .-$ & $74 \%$ vs. $63 \%$ & $0.63(0.25-1.54)$ & 0.307 \\
\hline HER 2 & $+v s .-$ & $69 \%$ vs. $69 \%$ & $0.90(0.36-2.25)$ & 0.826 \\
\hline P53 & $+v s .-$ & $73 \%$ vs. $68 \%$ & $0.82(0.31-2.16)$ & 0.523 \\
\hline CXCL8 & High $v s$. low & $56 \%$ vs. $80 \%$ & $2.58(1.01-6.55)$ & 0.047 \\
\hline Chemotherapy & Yes vs. no & $72 \%$ vs. $56 \%$ & $0.55(0.18-1.66)$ & 0.289 \\
\hline
\end{tabular}

HER2: Human epidermal growth factor receptor 2; CXCL8: C-X-C motif chemokine ligand 8; CI: confidence interval; HR: hazard ratio.

Table III. Patient overall survival (OS) in relation to Estrogen receptor-alpha (ER $\alpha)$ status and mRNA level of C-X-C motif chemokine ligand 8 (CXCL8).

\begin{tabular}{lcccccc}
\hline CXCL8 & ER $\alpha$ & 10-Year OS & HR $(95 \%$ CI)* & $p$-Value & HR $(95 \% \text { CI })^{\&}$ & $p$-Value \\
\hline Low & + & $81.5 \%$ & 1.00 & - & 1.00 & - \\
Low & - & $75.0 \%$ & $1.27(0.25-6.56)$ & 0.773 & $2.70(0.35-21.04)$ & 0.344 \\
High & + & $76.9 \%$ & $1.16(0.28-4.86)$ & 0.838 & $1.40(0.30-6.48)$ & 0.663 \\
High & - & $35.7 \%$ & $5.08(1.69-15.25)$ & 0.004 & $16.19(3.32-78.96)$ & $<0.001$ \\
\hline
\end{tabular}

*Univariate analysis. \&Adjusted for age, tumor size, progesterone receptor, human epidermal growth factor receptor 2, P53, chemotherapy and lymph node metastatic status.

Table IV. Multiple stepwise linear regression analysis of patient overall survival (OS).

\begin{tabular}{lllll}
\hline Clinicopathlogical parameter & 10 -Year OS & Multivariate* \\
\cline { 2 - 5 } & & & HR (95\% CI) & $p$-Value \\
\hline Tumor size, cm & $>2 v s . \leq 2$ & $58 \%$ vs. $78 \%$ & $3.61(1.37-9.52)$ & 0.009 \\
ER $\alpha$ & $-v s .+$ & $50 \%$ s. $80 \%$ & $2.85(1.12-7.24)$ & 0.028 \\
CXCL8 & High $v s$. low & $56 \%$ vs. $80 \%$ & $3.19(1.18-8.64)$ & 0.022 \\
\hline
\end{tabular}

ER $\alpha$ : Estrogen receptor-alpha; $C X C L 8$ : C-X-C motif chemokine ligand 8; CI: Confidence interval; HR: hazard ratio.*Adjusted for tumor size, ER $\alpha$ and $C X C L 8$.

investigated the important prognostic role of $C X C L 8$ in Chinese patients with ER $\alpha$-negative breast cancer. The statistical analysis (as shown in Figure 2) demonstrated the sensitivity and specificity of $C X C L 8$, the best cut-off point being at 3.095 for relative mRNA expression of $C X C L 8$. mRNA expression of $C X C L 8$ in breast cancer tissues had both high sensitivity and specificity for predicting 10-year OS rates. A positive correlation between the serum protein level of CXCL8 and progression of disease, and a negative correlation with survival rate of patients with breast cancer have been demonstrated (27-29). Zuccari et al. reported an inverse correlation between the CXCL8 protein levels determined by immunohistochemical staining and metastasis and/or local recurrence in patients with breast cancer (30). Herein, our results further confirmed that higher mRNA levels of CXCL8 were the negative prognostic significance for 10-year OS rates in Chinese breast cancer patients with $\mathrm{ER} \alpha$-negative expression. 
Breast cancer is one of the most common carcinomas in females with increasing morbidity worldwide. About 40-70\% of breast cancer growth is related to estrogen (31) and ER $\alpha$ status is an important index in breast cancer management. It is well-known that patients with $\mathrm{ER} \alpha$-positive breast cancer have a much better prognosis than those with ER $\alpha$-negative tumors (32). This difference is essentially due to the higher aggressiveness and invasiveness of ER $\alpha$-negative tumors. In the present study, we demonstrated that Chinese patients with ER $\alpha$-negative breast cancer had a relatively shorter OS Furthermore, we found that the CXCL 8 mRNA levels were significantly higher in patients with $\mathrm{ER} \alpha$-negative than in those with ER $\alpha$-positive disease, which could suggest that the mRNA level of CXCL8 in patient's breast cancer tissues may be negatively linked to their ER $\alpha$ status. Moreover, we found that $C X C L 8$ was overexpressed at the transcriptional level in Chinese patients with ER $\alpha$-negative cancer. This observation is consistent with those reported in previous studies showing potential significance of CXCL8 mRNA levels in relation to patient's $\mathrm{ER} \alpha$ status, i.e. CXCL8 expression level is negatively linked to $\mathrm{ER} \alpha$ status of breast and ovarian cancer cells (33-35). A study with a human cytokine antibody array confirmed that $C X C L 8$ was inversely associated with $\mathrm{ER} \alpha$ status, but positively associated with the metastatic potential of ER $\alpha$-negative breast cancer cells (36). Moreover, $C X C L 8$ expression was negatively linked to $\mathrm{ER} \alpha$ status of breast and ovarian cancer cells and associated with a higher invasiveness potential of cancer cells in vitro (37). A subgroup of patients with TNBC with a low CXCL8 expression level was characterized by a relatively low risk of recurrence, even in the absence of systemic therapy, and had a recurrence-free survival rate of $84 \%$ at 5 years (33). Our results demonstrate that patients with ER $\alpha$-negative breast cancer with increased expression of CXCL8 had only a survival rate of $35.7 \%$ at a median follow-up of 149.63 months (as shown in Table III).

A more recent study indicated that ER $\beta 1$ expression in archival TNBC specimens was related to significantly worse 5-year OS and that silencing ER $\beta$ expression significantly reduced TNBC proliferation and inhibition of ER $\beta$ expression with ER $\beta$-specific antagonist also reduced TNBC growth (38). Although in the present study we did not examine the ER $\beta$ status of the breast cancer tissues, it is likely that different ER $\beta$ isoforms may exist and play a role in these patients with breast cancer. Further study is needed to address this possibility.

In conclusion, this study has suggested that the mRNA level of CXCL8 in breast cancer tissue can be a promising prognostic biomarker for 10-year OS, especially for patients with the ER $\alpha$ negative type cancer, and that increased $C X C L 8$ expression may contribute to a worse patient's progress probably via increasing the invasiveness of cancer cells. The detailed mechanism underlying this, needs further investigation.

\section{Conflicts of Interest}

The Authors declare that they have no competing interests.

\section{Acknowledgements}

This research project was supported by a research grant from the Changzhou Science \& Technology Bureau (CJ20140028).

\section{References}

1 Yager JD and Davidson NE: Estrogen carcinogenesis in breast cancer. N Engl J Med 354(3): 270-282, 2006.

2 Matthews $\mathbf{J}$ and Gustafsson JA: Estrogen signaling: a subtle balance between ER alpha and ER beta. Mol Interv 3(5): 281292, 2003.

3 Zhao C, Dahlman-Wright $\mathrm{K}$ and Gustafsson JA: Estrogen signaling via estrogen receptor \{beta\}. J Biol Chem 285(51): 39575-39579, 2010.

4 Ali S and Coombes RC: Estrogen receptor alpha in human breast cancer: occurrence and significance. J Mammary Gland Biol Neoplasia 5(3): 271-281, 2000.

5 Katzenellenbogen BS and Frasor J: Therapeutic targeting in the estrogen receptor hormonal pathway. Semin Oncol 31(1 Suppl 3): 28-38, 2004.

6 Omoto $\mathrm{Y}$ and Iwase H: Clinical significance of estrogen receptor beta in breast and prostate cancer from biological aspects. Cancer Sci 106(4): 337-343, 2015.

7 Chen JQ and Russo J: ERalpha-negative and triple negative breast cancer: molecular features and potential therapeutic approaches. Biochim Biophys Acta 1796(2): 162-175, 2009.

8 Hudis CA and Gianni L: Triple-negative breast cancer: an unmet medical need. Oncologist 16(Suppl 1): 1-11, 2011.

9 Tomao F, Papa A, Zaccarelli E, Rossi L, Caruso D, Minozzi M, Vici P, Frati L and Tomao S: Triple-negative breast cancer: new perspectives for targeted therapies. Onco Targets Ther 8: 177193, 2015.

10 Russo RC, Garcia CC, Teixeira MM and Amaral FA: The CXCL8/IL-8 chemokine family and its receptors in inflammatory diseases. Expert Rev Clin Immunol 10(5): 593-619, 2014.

11 Zheng ZY, Tian L, Bu W, Fan C, Gao X, Wang H, Liao YH, Li Y, Lewis MT, Edwards D, Zwaka TP, Hilsenbeck SG, Medina D, Perou CM, Creighton CJ, Zhang XH and Chang EC: Wildtype N-Ras, overexpressed in basal-like breast cancer, promotes tumor formation by inducing IL-8 secretion via JAK2 activation. Cell Rep 12(3): 511-524, 2015.

12 Britschgi A, Radimerski T and Bentires-Alj M: Targeting PI3K, HER2 and the IL-8/JAK2 axis in metastatic breast cancer: Which combination makes the whole greater than the sum of its parts? Drug Resist Updat 16(3-5): 68-72, 2013.

13 Ning Y, Manegold PC, Hong YK, Zhang W, Pohl A, Lurje G, Winder T, Yang D, LaBonte MJ, Wilson PM, Ladner RD and Lenz HJ: Interleukin-8 is associated with proliferation, migration, angiogenesis and chemosensitivity in vitro and in vivo in colon cancer cell line models. Int J Cancer 128(9): 2038-2049, 2011.

14 Yao C, Lin Y, Chua MS, Ye CS, Bi J, Li W, Zhu YF and Wang SM: Interleukin-8 modulates growth and invasiveness of estrogen receptor-negative breast cancer cells. Int J Cancer 121(9): 1949-1957, 2007. 
15 Lin Y, Yin W, Yan T, Zhou L, Di G, Wu J, Shen Z, Shao Z and Lu J: Site-specific relapse pattern of the triple negative tumors in Chinese breast cancer patients. BMC Cancer 9: 342, 2009.

16 Puig-Vives M, Sanchez MJ, Sanchez-Cantalejo J, TorrellaRamos A, Martos C, Ardanaz E, Chirlaque MD, Perucha J, Diaz JM, Mateos A, Machon M and Marcos-Gragera R: Distribution and prognosis of molecular breast cancer subtypes defined by immunohistochemical biomarkers in a Spanish population-based study. Gynecol Oncol 130(3): 609-614, 2013.

17 Wolff AC, Hammond ME, Hicks DG, Dowsett M, McShane LM, Allison KH, Allred DC, Bartlett JM, Bilous M, Fitzgibbons P, Hanna W, Jenkins RB, Mangu PB, Paik S, Perez EA, Press MF, Spears PA, Vance GH, Viale G, Hayes DF, American Society of Clinical $\mathrm{O}$ and College of American P: Recommendations for human epidermal growth factor receptor 2 testing in breast cancer: American Society of Clinical Oncology/College of American Pathologists clinical practice guideline update. J Clin Oncol 31(31): 3997-4013, 2013.

18 Hammond ME, Hayes DF, Wolff AC, Mangu PB and Temin S: American society of clinical oncology/college of american pathologists guideline recommendations for immunohistochemical testing of estrogen and progesterone receptors in breast cancer. Journal of oncology practice 6(4): 195-197, 2010.

19 Wang Y, Xu RC, Zhang XL, Niu XL, Qu Y, Li LZ and Meng $\mathrm{XY}$ : Interleukin-8 secretion by ovarian cancer cells increases anchorage-independent growth, proliferation, angiogenic potential, adhesion and invasion. Cytokine 59(1): 145-155, 2012.

20 Biasi F, Guina T, Maina M, Nano M, Falcone A, Aroasio E, Saracco GM, Papotti M, Leonarduzzi G and Poli G: Progressive increase of matrix metalloprotease- 9 and interleukin- 8 serum levels during carcinogenic process in human colorectal tract. PLoS One 7(7): e41839, 2012.

21 Nastase A, Paslaru L, Niculescu AM, Ionescu M, Dumitrascu T, Herlea V, Dima S, Gheorghe C, Lazar V and Popescu I: Prognostic and predictive potential molecular biomarkers in colon cancer. Chirurgia (Bucur) 106(2): 177-185, 2011.

22 Chen Y, Shi M, Yu GZ, Qin XR, Jin G, Chen P and Zhu MH: Interleukin-8, a promising predictor for prognosis of pancreatic cancer. World J Gastroenterol 18(10): 1123-1129, 2012.

23 Urquidi V, Chang M, Dai Y, Kim J, Wolfson ED, Goodison S and Rosser CJ: IL-8 as a urinary biomarker for the detection of bladder cancer. BMC Urol 12: 12, 2012.

24 Waugh DJ, Wilson C, Seaton A and Maxwell PJ: Multi-faceted roles for CXC-chemokines in prostate cancer progression. Front Biosci 13: 4595-4604, 2008.

25 Bauer S, Adrian N, Siebenborn U, Fadle N, Plesko M, Fischer E, Wuest T, Stenner F, Mertens JC, Knuth A, Ritter G, Old LJ and Renner C: Sequential cancer immunotherapy: targeted activity of dimeric TNF and IL-8. Cancer Immun 9: 2, 2009.

26 Singh S, Singh AP, Sharma B, Owen LB and Singh RK: CXCL8 and its cognate receptors in melanoma progression and metastasis. Future Oncol 6(1): 111-116, 2010.

27 Derin D, Soydinc HO, Guney N, Tas F, Camlica H, Duranyildiz D, Yasasever V and Topuz E: Serum IL-8 and IL-12 levels in breast cancer. Med Oncol 24(2): 163-168, 2007.
28 Benoy IH, Salgado R, Van Dam P, Geboers K, Van Marck E, Scharpe S, Vermeulen PB and Dirix LY: Increased serum interleukin-8 in patients with early and metastatic breast cancer correlates with early dissemination and survival. Clin Cancer Res 10(21): 7157-7162, 2004.

29 Kozlowski L, Zakrzewska I, Tokajuk P and Wojtukiewicz MZ: Concentration of interleukin-6 (IL-6), interleukin-8 (IL-8) and interleukin-10 (IL-10) in blood serum of breast cancer patients. Rocz Akad Med Bialymst 48: 82-84, 2003.

30 Zuccari DA, Leonel C, Castro R, Gelaleti GB, Jardim BV, Moscheta MG, Regiani VR, Ferreira LC, Lopes JR, Neto Dde S and Esteves JL: An immunohistochemical study of interleukin8 (IL-8) in breast cancer. Acta Histochem 114(6): 571-576, 2012.

31 Nilsson S, Makela S, Treuter E, Tujague M, Thomsen J, Andersson G, Enmark E, Pettersson K, Warner $\mathrm{M}$ and Gustafsson JA: Mechanisms of estrogen action. Physiol Rev 81(4): 1535-1565, 2001.

32 Colombo PE, Milanezi F, Weigelt $\mathrm{B}$ and Reis-Filho JS: Microarrays in the 2010s: the contribution of microarray-based gene expression profiling to breast cancer classification, prognostication and prediction. Breast Cancer Res 13(3): 212, 2011.

33 Rody A, Karn T, Liedtke C, Pusztai L, Ruckhaeberle E, Hanker L, Gaetje R, Solbach C, Ahr A, Metzler D, Schmidt M, Muller V, Holtrich U and Kaufmann M: A clinically relevant gene signature in triple negative and basal-like breast cancer. Breast Cancer Res 13(5): R97, 2011.

34 Chavey C, Bibeau F, Gourgou-Bourgade S, Burlinchon S, Boissiere F, Laune D, Roques S and Lazennec G: Oestrogen receptor negative breast cancers exhibit high cytokine content. Breast Cancer Res 9(1): R15, 2007.

35 De Larco JE, Wuertz BR, Rosner KA, Erickson SA, Gamache DE, Manivel JC and Furcht LT: A potential role for interleukin8 in the metastatic phenotype of breast carcinoma cells. Am J Pathol 158(2): 639-646, 2001.

36 Vazquez-Martin A, Colomer R and Menendez JA: Protein array technology to detect HER2 (erbB-2)-induced 'cytokine signature' in breast cancer. Eur J Cancer 43(7): 1117-1124, 2007.

37 Freund A, Chauveau C, Brouillet JP, Lucas A, Lacroix M, Licznar A, Vignon F and Lazennec G: IL-8 expression and its possible relationship with estrogen-receptor-negative status of breast cancer cells. Oncogene 22(2): 256-265, 2003.

38 Hamilton N, Marquez-Garban D, Mah V, Fernando G, Elshimali Y, Garban H, Elashoff D, Vadgama J, Goodglick L and Pietras $\mathrm{R}$ : Biologic roles of estrogen receptor-beta and insulin-like growth factor-2 in triple-negative breast cancer. Biomed Res Int 2015: 925703, 2015.
Received June 24, 2017

Revised July 11, 2017

Accepted July 12, 2017 